\title{
Effect of chronic beta-adrenergic receptor blockade in congestive cardiomyopathy
}

\author{
F. Waagstein, A. Hjalmarson, E. Varnauskas, and I. Wallentin \\ From the Department of Medicine I, Division of Cardiology and Department of Clinical Physiology, Sahlgren's \\ Hospital, University of Göteborg, Sweden
}

Adrenergic beta-blocking agents were given to 7 patients with advanced congestive cardiomyopathy who had tachycardia at rest $(98 \pm I 3$ beats/min). The patients were on beta-adrenergic receptor blockade for 2 to I2 months (average 5.4 months). One patient was given alprenolol $50 \mathrm{mg}$ twice daily and the other patients were given practolol 50 to $400 \mathrm{mg}$ twice daily. Virus infection had occurred in 6 of the patients before the onset of symptoms of cardiac disease. All patients were in a steady state or were progressively deteriorating at the start of beta-adrenergic receptor blockade. Conventional treatment with digitalis and diuretics was unaltered or reduced during treatment with beta-blocking agents. An improvement was seen in their clinical condition shortly after administration of the drugs. Continued treatment resulted in an increase in physical working capacity and a reduction of heart size.

Noninvasive investigations including phonocardiogram, carotid pulse curve, apex cardiogram, and echocardiogram showed improved ventricular function in all cases. The present study indicates that adrenergic beta-blocking agents can improve heart function in at least some patients with congestive cardiomyopathy. Furthermore, it is suggested that increased catecholamine activity may be an important factor for the development of this disease, as has been shown in animal experiments.

Conventional therapy in congestive cardiomyopathy has failed to change the final outcome of the disease (Goodwin and Oakley, 1972). It was recently stated (Goodwin, 1974) that, 'at the present time the prognosis for severe congestive cardiomyopathy is so bleak and treatment so unsatisfactory that cardiac transplantation may be considered in desperate cases'. Despite reduction in heart size with bed rest, which is also seen in normal people who are immobilized (Saltin et al., 1968), relapse has occurred in many cases after mobilization. The rate of thromboembolic complications has been high (McDonald, Burch, and Walsh, 1972). Several other disadvantages may be expected from prolonged bed rest (Deitrick, Whedon, and Shorr, 1948).

In a recent study immediate relief from ischaemic chest pain was reported when the cardioselective beta-adrenergic receptor agent practolol was given to patients with acute myocardial infarction. The drug was well tolerated though some of these patients had signs of latent left-sided heart failure (Waagstein, Hjalmarson and Wasir, 1974). In some patients with acute myocardial infarction, acute congestive heart failure, and supraventricular tachyReceived 18 November 1974. cardia, which did not respond to conventional therapy such as digitalis and frusemide, the injection of practolol was followed by disappearance of the signs of pulmonary congestion ( $F$. Waagstein and $\AA$. Hjalmarson, unpublished data). It was thought that the positive effect in these patients was the result of a decrease in left ventricular external work expressed as the product of systolic

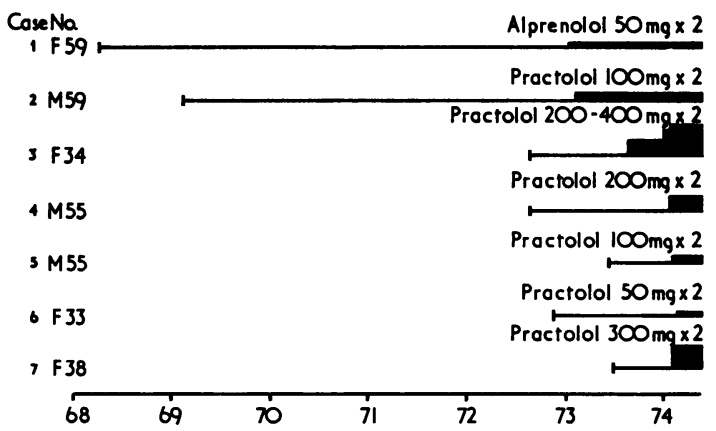

FIG. I Duration of heart disease in years and treatment with beta-adrenergic receptor blocking agents in patients with congestive cardiomyopathy. 
blood pressure and heart rate. On the basis of these findings it was considered that patients with congestive heart failure from other causes might also respond well to a reduction of tachycardia by betaadrenergic receptor blockade.

In the present study adrenergic beta-blocking agents were, therefore, given to patients with congestive cardiomyopathy of unknown origin, with long-standing signs of cardiac failure and a resting heart rate of about 100 beats $/ \mathrm{min}$. The effect of the treatment with beta-adrenergic blockade on their clinical condition, physical working capacity, and heart function, as judged from noninvasive techniques, forms the basis of this report.

\section{Subjects}

Seven patients, 3 men and 4 women, 33 to 59 years of age ( $47.5 \pm$ II.9) with a history of heart disease ranging from 6 months to 6 years $(2.6 \pm 2.2)$ were studied (Fig. I). The patients were chosen on the basis of a diagnosis of cardiomyopathy with congestive heart failure and an increased heart rate at rest. Their heart rates were 85 to II5 (98 \pm 13 ) beats $/ \mathrm{min}$. The diagnosis of congestive cardiomyopathy was based on the criteria given by Goodwin and Oakley (1972). Patients with overt coronary heart disease, congenital heart disease, acquired valvular disease, and hypertensive heart disease were excluded. Coronary angiograms were obtained in 2 patients (Cases I and 6) and were normal.

All patients were in a steady state or were deteriorating progressively at the start of therapy with the betaadrenergic receptor blocking agents. None of the patients had suffered during three months before the start of betablockade from any acute episode of disease indicating acute myocarditis, acute coronary heart disease, or acute embolism, for example.

The patients were on oral treatment with digitalis (digoxin) and diuretics (frusemide, spironolactone) for congestive heart failure, except for one (Case 7) who received only digitalis. Two patients (Cases 2 and 6 ) had been given parenteral injections of ethacrynic acid or frusemide in addition. The treatment with digitalis and diuretics was unaltered or reduced during the time that practolol was given. The clinical data are given in the case reports below and in Fig. I and Table I.

\section{Representative case reports}

Case I A 59-year-old woman had septicaemia at the age of 25. No sign of heart disease was seen at that time. In 1962 a routine medical examination revealed third and fourth heart sounds but electrocardiogram and $x$-ray of the heart were normal. The patient had no cardiac symptoms except for infrequent ectopic beats. In April 1968 heart failure developed rapidly over a period of a few weeks, culminating in pulmonary oedema. No clinical evidence of infection was present. Erythrocyte sedimentation rate, white blood cells, temperature, and virus titres taken on two occasions, were normal. Electrocardiogram showed left ventricular hypertrophy but the heart volume derived from the $x$-ray was $800 \mathrm{ml}$ or $4 \mathrm{ro} \mathrm{ml}$ per $\mathrm{m}^{2}$. The patient improved on digitalis and diuretics. Left ventricular catheterization revealed a left ventricular end-diastolic pressure of $19 \mathrm{mmHg}$ $(2.5 \mathrm{kPa})$. Selective coronary angiogram was normal. The patient continued to have effort dyspnoea and was graded in functional group II until April 1972 when her symptoms grew worse, with increasing dyspnoea and peripheral oedema. From August 1972 the patient shifted between functional groups III and IV. During 6 months the patient was admitted to hospital on 4 occasions for a total of $2 \frac{1}{2}$ months. Chest $x$-ray showed a pronounced increase in heart size (see Table 4 and Fig. 7), and right heart catheterization showed an increase in the mean pulmonary arterial pressure. Loud diastolic extra sounds, shortened left ventricular ejection time, and highly pathological apex cardiogram and echocardiogram were also recorded (see Tables 5 to 8 and Fig. 2). In January 1973, atrial fibrillation occurred which was easily converted by DC shock. The patient was given

TABLE I Clinical and electrocardiographic findings in 7 cases of congestive cardiomyopathy before start of beta-blockade

\begin{tabular}{|c|c|c|c|c|c|c|c|c|c|}
\hline $\begin{array}{l}\text { Case } \\
\text { No. }\end{array}$ & Sex & $\begin{array}{l}A g e \\
(y r)\end{array}$ & $\begin{array}{l}\text { Possible virus } \\
\text { infection }\end{array}$ & $\begin{array}{l}\text { Chest pain } \\
\text { on exercise }\end{array}$ & $\begin{array}{l}\text { Dyspnoea } \\
\text { on exercise }\end{array}$ & $\begin{array}{l}\text { Peripheral } \\
\text { oedema }\end{array}$ & Ascites & Rhythm & $Q R S$ complex \\
\hline I & $\mathbf{F}$ & 59 & - & - & + & + & - & Sinus & Left ventricular \\
\hline 2 & $\mathbf{M}$ & 59 & $(+)$ & - & + & + & - & $\begin{array}{c}\text { Atrial } \\
\text { fibril- } \\
\text { lation }\end{array}$ & $\begin{array}{l}\text { hypertrophy } \\
\text { Left bundle-branch block }\end{array}$ \\
\hline $\begin{array}{l}3 \\
4\end{array}$ & $\begin{array}{l}\mathbf{F} \\
\mathbf{M}\end{array}$ & $\begin{array}{l}34 \\
55\end{array}$ & + & \pm & $\begin{array}{l}+ \\
+\end{array}$ & + & $\overline{-}$ & $\begin{array}{l}\text { Sinus } \\
\text { Sinus }\end{array}$ & Left ventricular \\
\hline $\begin{array}{l}5 \\
6\end{array}$ & $\begin{array}{l}\mathbf{M} \\
\mathbf{F}\end{array}$ & $\begin{array}{l}55 \\
33\end{array}$ & $\stackrel{+}{+}$ & $\stackrel{(+)}{-}$ & $\begin{array}{l}+ \\
+\end{array}$ & $\begin{array}{l}+ \\
+\end{array}$ & $\bar{t}$ & $\begin{array}{l}\text { Sinus } \\
\text { Nodal }\end{array}$ & $\begin{array}{l}\text { Left bundle-branch block } \\
\text { Left anterior hemiblock }\end{array}$ \\
\hline 7 & $\mathbf{F}$ & 38 & + & - & + & - & - & Sinus & $\begin{array}{l}\text { Left ventricular } \\
\text { hypertrophy }\end{array}$ \\
\hline
\end{tabular}




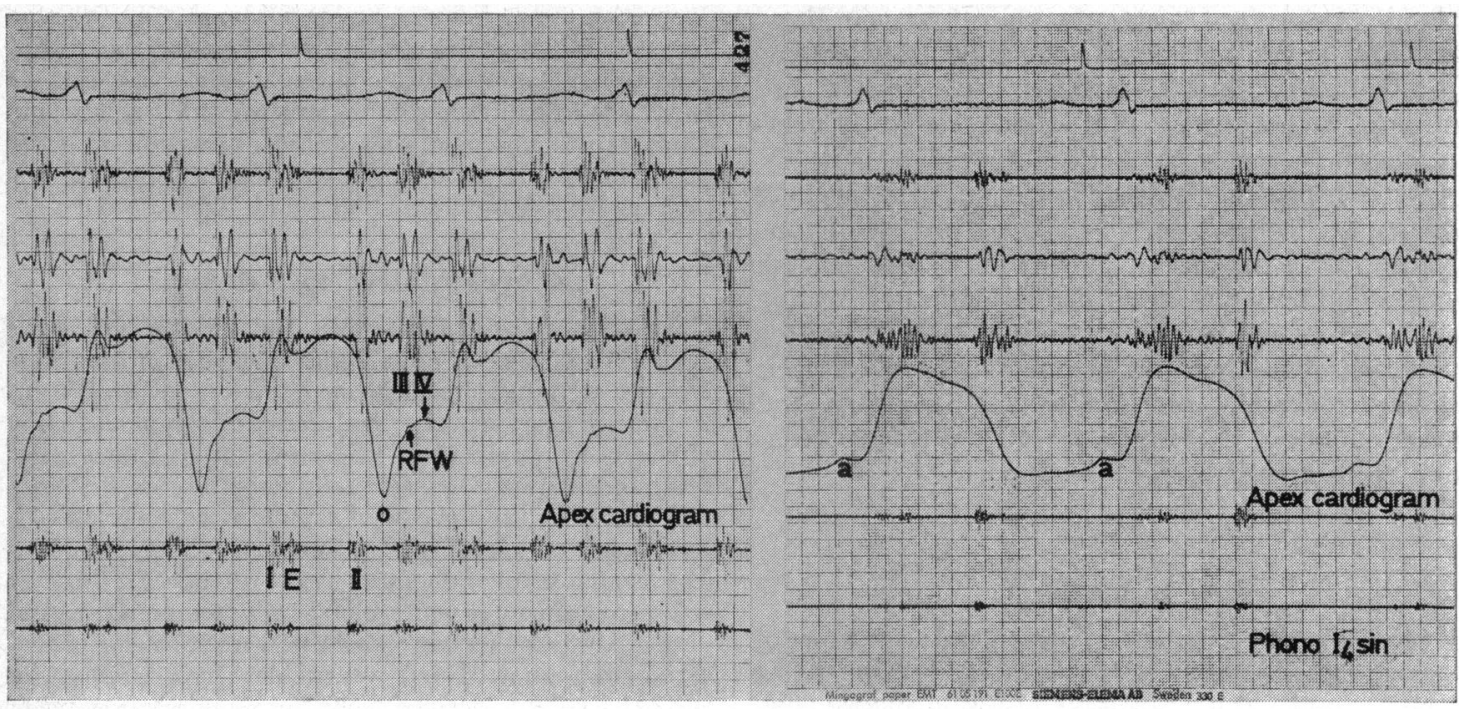

$a$

$b$

FIG. 2 Case I. Phonocardiogram and apex cardiogram before beta-blockade (a) and I 2 months after (b). Note the total disappearance of a very strong third heart sound and reduced amplitude of the fourth heart sound. The ejection sound, $E$, is almost unchanged. In the apex cardiogram, note that the early diastolic rise to a very high rapid filling wave $(R F W)$ has changed to a normal diastolic filling pattern after 12 months of beta-blockade. From above: ECG lead II; PCG: earlike, $25 \mathrm{~Hz}$, $50 \mathrm{~Hz}$, apex cardiogram, $200 \mathrm{~Hz}$ and $400 \mathrm{~Hz}$.

quinidine. Severe dyspnoea at rest persisted and the resting heart rate averaged II I beats/min. The patient then had $0.25 \mathrm{mg}$ digoxin, 40 to $80 \mathrm{mg}$ frusemide, and $0.8 \mathrm{~g}$ quinidine sulphate daily and was later given the beta-blocking agent alprenolol $50 \mathrm{mg}$ twice daily. The heart rate was reduced to 90 beats/min and an immediate relief of orthopnoea was seen within a few days. During the following 2 to 3 months there was clinical improvement. Reinvestigation 12 months later confirmed this improvement (see Tables 3, 5 to 8 and Fig. 2). At that time the patient was on digoxin, frusemide, quinidine, and alprenolol.

Case 2 A 50-year-old carpenter had suffered from recurrent throat infections of long duration since 1966. Antibiotics were given but the patient always stayed at work despite high fever. In February 1969, about one month after a throat infection, he suddenly developed exertional dyspnoea and retrosternal pain on deep inspiration. The pain disappeared after one week but the dyspnoea increased steadily, culminating in pulmonary oedema. On admission to hospital he had atrial fibrillation, with a ventricular rate of 160 beats/min. Some improvement was seen after digitalis and diuretics but the atrial fibrillation persisted with a ventricular rate of about I Io beats/min at rest. DC conversion was not done at this time. The heart size was $690 \mathrm{ml}$ per $\mathrm{m}^{2}$.
Slow deterioration occurred until December I97I when he was in functional group III-IV. From that time he was admitted to hospital 9 times for a total of $2 \frac{1}{2}$ months until treatment with the beta-blocker was started. During the short periods at home he suffered from severe nocturnal dyspnoea and he had to sleep in the sitting position. In addition, since I969, the patient had short attacks of fainting related to exercise of moderate intensity. The frequency of the attacks was still increasing. Observation with telemetry and tape recording of electrocardiogram failed to reveal episodes of bradyarrhythmia or ventricular tachyarrhythmia. Electrocardiogram was normal and no effect was seen after therapeutic trials with different anticonvulsants. The attacks were, therefore, interpreted as being caused by inadequate cardiac output during exercise. In February I973 treatment with practolol was started, resulting in improvement and disappearance of the nocturnal dyspnoea within a few days. It was then possible to withdraw spironolactone and the intermittent injections of frusemide. The resting heart rate was reduced (see Table 2) and an improvement in working performance was seen (see Table 3). The episodes of fainting were then infrequent. In March 1974 he underwent an operation for a perforated appendix. The postoperative period was complicated by wound infection but he was nevertheless in good cardiopulmonary condition. Noninvasive investigation including echocardiography, which was 
TABLE 2 Resting blood pressure and heart rate before and during chronic beta-blockade

\begin{tabular}{|c|c|c|c|c|c|c|c|c|c|}
\hline \multirow[t]{2}{*}{ Case No. } & \multicolumn{3}{|c|}{ Shortly before beta-blockade } & \multicolumn{3}{|c|}{$\begin{array}{l}\text { After } 3 \text { to } 7 \text { days on beta- } \\
\text { blockade }\end{array}$} & \multicolumn{3}{|c|}{$\begin{array}{l}\text { After } 2 \text { to I } 2 \text { months on beta- } \\
\text { blockade }\end{array}$} \\
\hline & $\begin{array}{l}\text { Systolic } \\
B P \\
(m m H g)\end{array}$ & $\begin{array}{l}\text { Diastolic } \\
B P\end{array}$ & $H R$ & $\begin{array}{l}\text { Systolic } \\
B P\end{array}$ & $\begin{array}{l}\text { Diastolic } \\
B P\end{array}$ & $H R$ & $\begin{array}{l}\text { Systolic } \\
B P\end{array}$ & $\begin{array}{l}\text { Diastolic } \\
B P\end{array}$ & $H R$ \\
\hline I & 137 & 80 & III & II5 & 80 & 90 & 137 & 75 & $8 I$ \\
\hline 2 & 126 & 87 & IIS & 125 & 87 & 82 & 142 & 82 & 74 \\
\hline 3 & IIO & 80 & 97 & IOI & 64 & 91 & 105 & 69 & 87 \\
\hline 4 & 113 & $8 I$ & 107 & 102 & 64 & 91 & 128 & 61 & 74 \\
\hline 5 & 145 & 87 & 83 & 140 & 80 & 68 & 135 & 78 & 60 \\
\hline 6 & 106 & 70 & 86 & 100 & 65 & 53 & IIO & 80 & 38 \\
\hline 7 & 158 & 80 & 85 & 148 & 80 & 75 & 130 & 68 & 71 \\
\hline Mean $\pm S D$ & $129 \pm 21$ & $81 \pm 6$ & $98 \pm 13$ & $118 \pm 20$ & $74 \pm$ I0 & $79 \pm 14$ & $126 \pm 14$ & $73 \pm 8$ & $69 \pm 16$ \\
\hline
\end{tabular}

Note: Values are means of at least 5 measurements. Conversion factor from Traditional to SI units: $1 \mathrm{mmHg} \approx 0.133 \mathrm{kPa}$.

only performed after chronic beta-blockade, showed signs of general cardiomyopathy and no sign of outflow obstruction. A clear reduction of heart size was seen (see Table 4). Attempts to withdraw the beta-blocking agent were followed by immediate relapse of nocturnal dyspnoea and more frequent attacks of fainting.

Case 4 A 55-year-old man had recurrent duodenal ulcers since 1940. In 1971, his stomach was resected for acute stenosis. He had never complained about his stomach since that time. Heart size at the time of operation was $335 \mathrm{ml}$ per $\mathrm{m}^{2}$. Electrocardiogram and blood pressure as well as the resting heart rate were normal.

In September 1972 the patient developed a common cold, and in the subsequent 2 weeks he went into cardiac failure. Erythrocyte sedimentation rate, leucocytes, temperature, and virus titres were within the normal range. Electrocardiogram now showed left ventricular hypertrophy. The heart size was still within the normal range (390 ml per $\mathrm{m}^{2}$ ) but the apex cardiogram was pathological with an a/H ratio of 26 per cent but a normal rapid filling wave. Improvement was seen after digitalis and diuretics and the patient's condition was stable in functional group II to III until June 1973. He then caught a common cold again, and after that the disease progressed rapidly, with development of nocturnal
TABLE. 3 Physical work test before and after chronic beta-blockade

\begin{tabular}{llll}
\hline $\begin{array}{l}\text { Case } \\
\text { No. }\end{array}$ & $\begin{array}{l}\text { Shortly before } \\
\text { beta-blockade } \\
(\mathrm{kpm} / \mathrm{min})\end{array}$ & $\begin{array}{l}\text { After } 3 \text { to } 7 \\
\text { days on beta- } \\
\text { blockade } \\
(\mathrm{kpm} / \mathrm{min})\end{array}$ & $\begin{array}{l}\text { After 2 to I2 } \\
\text { months on beta- } \\
\text { blockade } \\
(\mathrm{kpm} / \mathrm{min})\end{array}$ \\
\hline I & FG IV & - & 500 \\
2 & FG IV & - & 500 \\
3 & 400 & 400 & 500 \\
4 & 300 & 300 & 600 \\
5 & 450 & 600 & 750 \\
6 & 200 & 300 & 400 \\
7 & 300 & 400 & 500 \\
\hline
\end{tabular}

Note: Values are means of at least 5 measurements.

FG = functional grade.

dyspnoea and pleural effusion. He was taken into hospital in January 1974 in a bad condition with dyspnoea and a clinical picture of low cardiac output syndrome with faint radial pulses, coldness of the periphery, and severe acrocyanosis. He could hardly walk and complained of dizziness in the upright position.

TABLE 4 Heart volumes and body weight before and 2 to 12 months after chronic beta-blockade

\begin{tabular}{|c|c|c|c|c|c|c|}
\hline \multirow[t]{2}{*}{ Case No. } & \multicolumn{3}{|c|}{ Before beta-blockade } & \multicolumn{3}{|c|}{ After beta-blockade } \\
\hline & $\begin{array}{l}\text { Total heart } \\
\text { volume }(\mathrm{ml})\end{array}$ & $\begin{array}{l}\text { Heart } \\
\text { volume per } m^{2} B S A(m l)\end{array}$ & $\begin{array}{l}\text { Body weight } \\
(\mathrm{kg})\end{array}$ & $\begin{array}{l}\text { Total heart } \\
\text { volume }(m l)\end{array}$ & $\begin{array}{l}\text { Heart } \\
\text { volume per } m^{2} B S A(m l)\end{array}$ & $\begin{array}{l}\text { Body weight } \\
(\mathrm{kg})\end{array}$ \\
\hline $\mathbf{I}$ & 1430 & 830 & 58.5 & 880 & 460 & 63.5 \\
\hline 2 & 2300 & 1030 & 102.5 & 1790 & 790 & 115.7 \\
\hline 3 & 1440 & 800 & 76.9 & II90 & 680 & 73.0 \\
\hline 4 & I 160 & 670 & 57.2 & 910 & 500 & 66.2 \\
\hline 5 & 1740 & 880 & 82.0 & 1590 & 820 & 82.0 \\
\hline 6 & 1370 & 820 & 56.9 & 1380 & 820 & $57 \cdot 3$ \\
\hline 7 & 585 & 380 & 53.0 & 585 & 390 & 50.5 \\
\hline
\end{tabular}




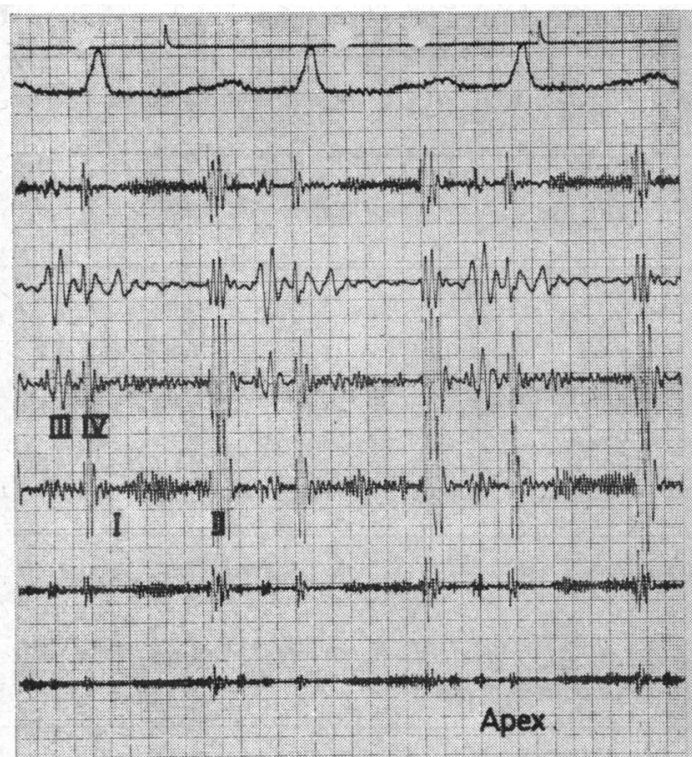

$a$



$c$

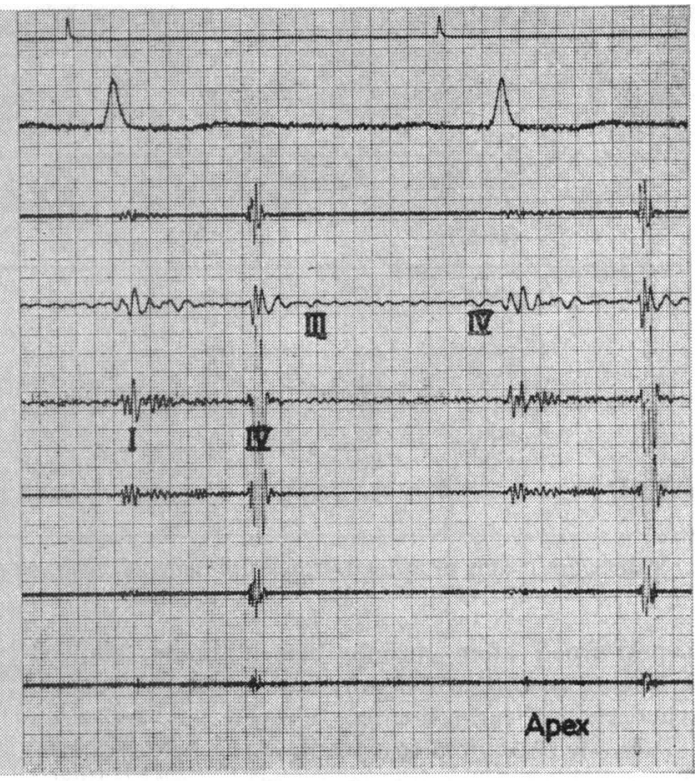

$b$

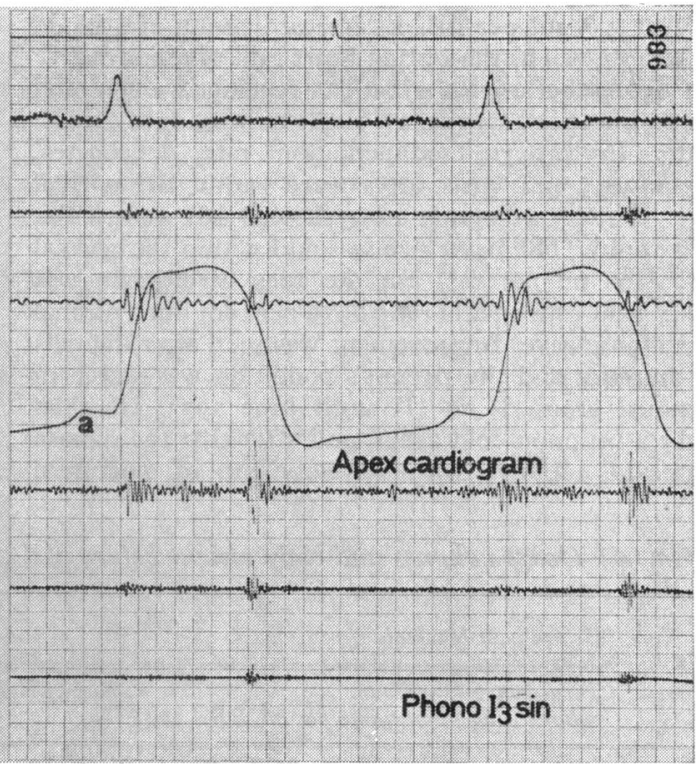

$d$

FIG. 3 Case 4. Phonocardiogram and apex cardiogram before ( $a$ and c, respectively), and after 2 months of beta-blockade ( $b$ and $d$, respectively). Note that the initial regurgitation murmur disappears and the strong third and fourth heart sounds decrease to normal amplilitudes; the filling pattern of the apex cardiograms also returns to normal after beta-blockade. 
Noninvasive investigation showed signs of increased filling pressure of the left ventricle in early diastole (see Table 7 and Fig. 3) and enlarged left ventricular diameter (see Table 8) and small stroke volume (see Table 6). This was confirmed by left and right heart catheterization and increased heart size in $x$-ray (see Table 4). After administration of practolol there was no immediate effect, but after about one month improvement was seen which was still in progress three months later. Initially the arterial hypotension and dizziness in the upright position previously seen were somewhat accentuated. After 2 months these symptoms had completely disappeared. The patient is now in a better condition than before the start of the disease in September 1972. Reinvestigation showed improvement in all invasive parameters ${ }^{1}$ as well as noninvasive parameters, except for an unchanged left ventricular diameter (see Tables 3-8 and Fig. 3).

\section{Methods}

Resting blood pressures and heart rates were calculated as the mean of at least 5 observations with the patient lying in bed in the morning.

Exercise tests were performed on an electrically braked bicycle-ergometer (Elema-Schönander EM 369/I). The maximum attainable work loads were expressed in $\mathrm{kpm} / \mathrm{min}(\mathrm{r} \mathrm{kpm} / \mathrm{min}=0.16 \mathrm{~W})$. The patients were kept for 4 minutes on each work load. The work loads were increased stepwise in the same manner before and after beta-blockade.

Heart volumes were measured from a chest $x$-ray taken in the standing position, according to Jonsell (I939) and expressed in $\mathrm{ml}$ per $\mathrm{m}^{2}$ body surface area.

Noninvasive investigations were performed in all patients, including phonocardiogram from 5 standard areas, apex cardiogram, pulse tracings from the carotid artery, jugular vein, and liver, and echocardiogram. All tracings with the exception of the echocardiograms were made with an 8-channel ink-recorder (Mingograph 8I, Elema-Schönander) at a paper speed of $100 \mathrm{~mm} / \mathrm{s}$. The phonocardiograms were recorded with an acceleration microphone (type Elema-Schönander EMT 25C) fixed to the thoracic wall with adhesive tape. The apex cardiogram and the pulse tracings were all done with a special handheld funnel-shaped pickup (Wikstrand, Wallentin, and Nilsson, to be published) with an internal diameter of $2.3 \mathrm{~cm}$ connected to a crystal transducer (Elema-Schönander EMT $510 \mathrm{C}$ ) with a $35 \mathrm{~cm}$ latex tube. This combined system has a frequency response of $0.09-60 \mathrm{~Hz}(-3 \mathrm{db})$ and a time constant of r.8-4.6 s (depending on the amplification). The left ventricular ejection time was measured from the carotid pulse and corrected for the heart rate according to Meiners (Meiners, 1958; Hartman, 1964; Willems and Kesteloot, 1967). This correction expresses left ventricular ejection time as a percentage of the normal for the heart rate concerned. The apex cardiogram was recorded with

1 These data will be published in a future communication. the patient in the left lateral position. The a wave was expressed as a percentage of the total amplitude of the pulse curve $(\mathbf{H})$. Analogous to this conventional $\mathrm{a} / \mathrm{H}$ ratio, the rapid filling wave (RFW) was also expressed as the $\mathrm{RFW} / \mathrm{H}$ ratio, since most changes were seen in the early diastolic part of the apex cardiogram because of the very disturbed left ventricular function of the patients in this study. All measurements were calculated as the mean of at least 3 cardiac cycles.

Echocardiography: a commercially available ultrasonoscope (Ekoline 20, Mark II, Smith-Kline) was employed, using a $2.25 \mathrm{MHz}$ transducer, with $10 \mathrm{~cm}$ focus and with a repetition rate of 1000 impulses/s. Polaroid photographs of the time-motion echo display were taken from a slave storage oscilloscope (Tektronix 603). The standard technique (Feigenbaum, 1972) of examining the mitral and aortic valves and the size of the left atrium and left ventricle was followed. Much care and time were taken to get the anteroposterior diameter of the left ventricle just below the aortic root and through or very close to both the anterior and posterior mitral leaflets. In order to standardize the measurement of the left atrium the beam had to go through and visualize the aortic leaflets as well. The stroke volume was calculated from the end-diastolic and end-systolic volumes derived by the cube method (Pombo, Troy, and Russell, 197I) and the ejection fraction from the stroke volume and end-diastolic volume. The mean rate of circumferential fibre shortening (mean $\mathrm{V}_{\mathrm{CF}}$ ) was calculated according to Cooper and co-workers (1972), with the exception that left ventricular ejection time in the formula was derived from the carotid pulse curve.

\section{Results}

Adrenergic beta-receptor blocking agents were given for 2 to 12 months (Fig. I) to the 7 patients (Table I). One patient was given alprenolol in a dose of $50 \mathrm{mg}$ twice daily and the other 6 patients were given practolol in a dose of 50 to $400 \mathrm{mg}$ twice daily. Before the treatment with beta-blocking agents these patients had severe manifestations of congestive cardiomyopathy as described in the case reports above. Four patients experienced an immediate reduction of dyspnoea and retrosternal oppression. The 3 remaining patients reported a gradual improvement starting after one month of treatment. Two patients with peripheral oedema and ascites, which had been resistant to large doses of diuretics, had a diuresis after the beta-blockade and were maintained free of oedema with lower doses of diuretics or none at all (see Table 9). In 3 patients (Cases I, 2, and 4) the improvement was considerable and a clear improvement was seen in Cases 5 to 7 , whereas the changes were less in Case 3, but even this patient reported improved exercise performance. The patients generally complained of muscle tiredness at the beginning of beta-blockade, even at a low degree of physical exercise, and 
TABLE 5 Amplitudes of the heart sounds as judged from phonocardiograms before and 2 to 12 months after chronic beta-blockade

\begin{tabular}{|c|c|c|c|c|c|c|}
\hline \multirow[t]{2}{*}{$\begin{array}{l}\text { Case } \\
\text { No. }\end{array}$} & \multicolumn{2}{|c|}{$\begin{array}{l}\text { Pulmonary } \\
\text { component of 2nd } \\
\text { heart sound }\end{array}$} & \multicolumn{2}{|c|}{ 3rd heart sound } & \multicolumn{2}{|c|}{ 4th heart sound } \\
\hline & Before & After & Before & After & Before & After \\
\hline I & 4 & $\begin{array}{l}N(2) \\
N(I-2)\end{array}$ & 5 & $\begin{array}{l}0 \\
0\end{array}$ & 4 & $\stackrel{2}{\text { - }}$ \\
\hline 3 & $3-4$ & $3-4$ & 0 & 0 & 3 & 2 \\
\hline 4 & 4 & $N(2)$ & 4 & $\mathbf{I}$ & 5 & $\mathbf{I}$ \\
\hline 5 & 4 & $\mathbf{N}(2-3)$ & 3 & 2 & 4 & 2 \\
\hline 6 & 4 & $N(2-3)$ & 4 & 3 & - & $-\dagger$ \\
\hline 7 & $3-4$ & $\mathbf{N}(2)$ & 5 & 0 & 4 & I \\
\hline
\end{tabular}

* Atrial fibrillation.

+ Nodal rhythm.

Note: Amplitude of sounds are judged on subjective 5-degree scale. $O=$ no detectable component; $I=$ very weak heart sound; 2 =weak heart sound; $3=$ moderate heart sound; $4=$ strong heart sound; $5=$ very strong heart sound; $N=$ normal heart sound. See text for further explanation.

dizziness when standing. After $\mathrm{I}$ to 2 months of treatment these symptoms had almost completely disappeared.

\section{Resting heart rate and blood pressure}

The heart rate and the systolic blood pressure decreased shortly after the start of beta-blockade (Table 2). A further reduction in heart rate was seen at the time of reinvestigation, whereas the resting systolic blood pressure tended to return to the same level as before beta-blockade. The diastolic blood pressure fell somewhat just after the start of beta-blockade and then remained at this lower level.

TABLE 6 Relative left ventricular ejection time before and after chronic beta-blockade in congestive cardiomyopathy

\begin{tabular}{lll}
\hline $\begin{array}{l}\text { Case } \\
\text { No. }\end{array}$ & Before (\%) & After (\%) \\
\hline I & 85 & 92 \\
2 & $\frac{1}{85}$ & 80 \\
3 & 74 & 92 \\
4 & 92 & 95 \\
5 & 64 & 80 \\
6 & 87 & 90 \\
7 & & \\
\hline
\end{tabular}

Note: Left ventricular ejection time is rate-corrected according to Meiners (1958) and expressed as a percentage of normal.
TABLE 7 Apex cardiogram before and after chronic beta-blockade in congestive cardiomyopathy

\begin{tabular}{lllll}
\hline \multirow{2}{*}{$\begin{array}{l}\text { Case } \\
\text { No. }\end{array}$} & \multicolumn{2}{l}{$R F W \mid H(\%)$} & \multicolumn{2}{l}{$a / H(\%)$} \\
\cline { 2 - 5 } & Before & After & Before & After \\
\hline I & 38 & 2 & 9 & 9 \\
2 & - & 8 & -1 & $4^{\star}$ \\
3 & 17 & 22 & 16 & 19 \\
4 & 17 & 5 & 11 & 7 \\
5 & 11 & $0-1$ & 31 & 35 \\
6 & 50 & 12 & $-\dagger$ & $-\dagger$ \\
7 & 22 & 5 & 27 & 5 \\
\hline
\end{tabular}

* Atrial fibrillation, no a wave.

$\dagger$ Nodal rhythm, no a wave.

$\mathrm{RFW}=$ rapid filling wave; $\mathrm{H}=$ total amplitude of pulse curve; $a=$ height of a wave.

\section{Exercise test}

A slight improvement was recorded I to 3 days after commencement of the treatment with betablocking agents. Later there was a further rise in physical working capacity (Table 3 ) and the systolic blood pressure increased to a higher level during exercise as compared to the pretreatment level. During beta-blockade treatment the exercise test was interrupted because of muscle fatigue or general exhaustion rather than because of dyspnoea, palpitation, or retrosternal oppression, as was the case in the pretreatment exercise test.

\section{$X$-ray of the heart}

A significant reduction of heart size as judged from chest $x$-ray was seen in 3 (Cases I, 2, and 4) out of the 6 cases with enlarged hearts (Table 4). Some reduction occurred in Case 3. In 2 cases the heart size was unaltered.

\section{Phonocardiogram}

The amplitude of the pulmonary component of the second heart sound and of the diastolic extra sounds was judged according to a subjective 5-degree scale (Table 5). A fourth heart sound and pulmonary component of degree 4 to 5 were considered pathological. Since clear-cut third heart sounds are always pathological in this age group, even degree 3 was considered abnormal. Because of poor clinical condition, Case 2 was not investigated before the start of beta-blockade. Case 3 had an enormously dilated left ventricle and weak and diffuse heart sounds. The other 5 patients had moderate to strong third heart sounds, which in Cases 1,4 , and 7 disappeared after beta-blockade (Fig. 2-4). A decrease in amplitude occurred in the other 2 cases. Of 5 




$a$

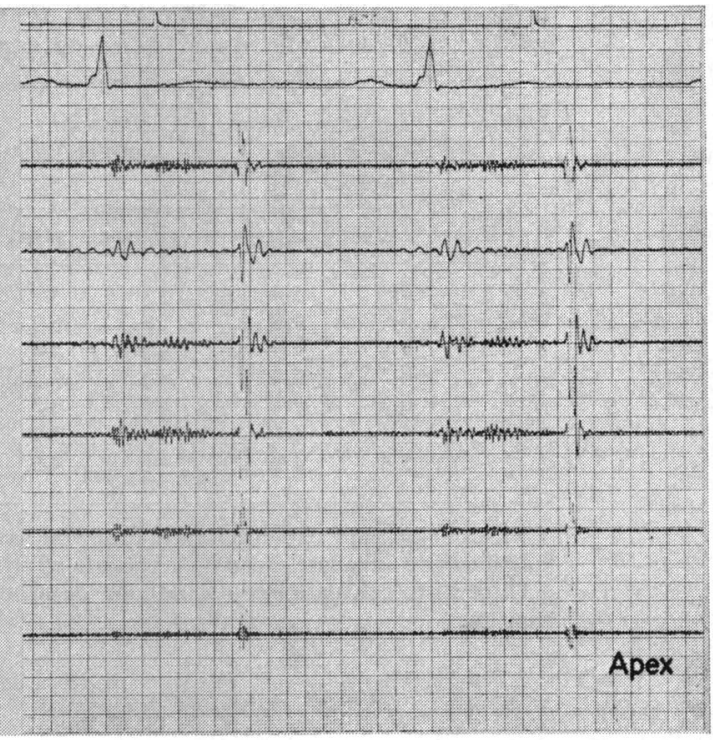

$b$

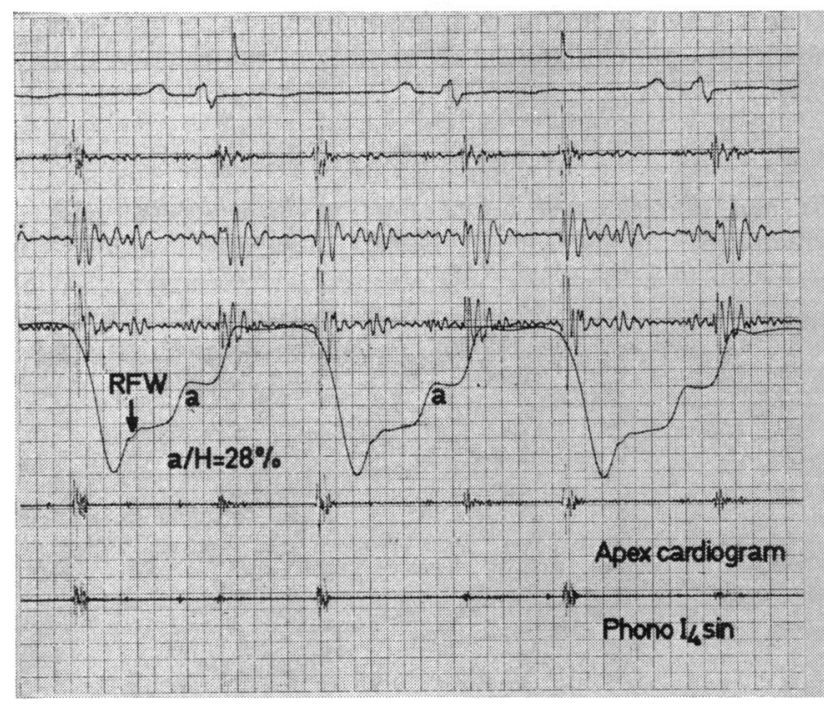

$c$

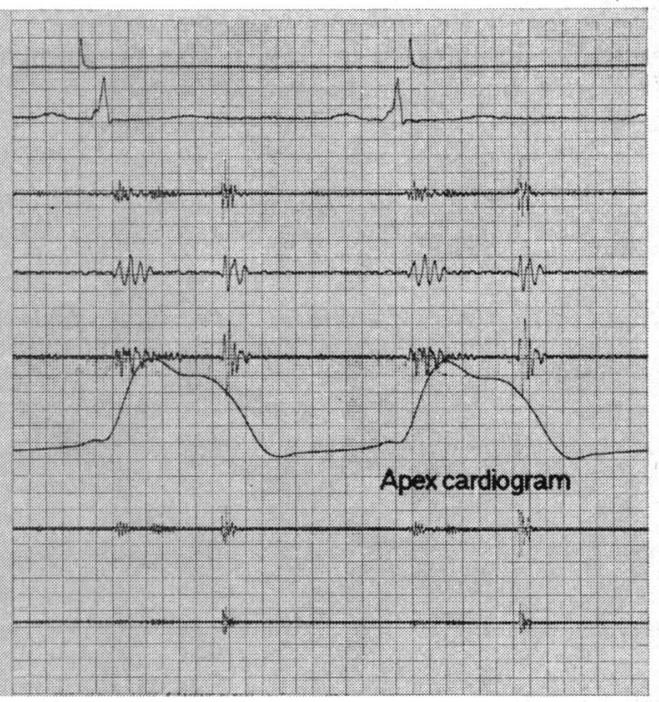

$d$

FIG. 4 Case 7. Phonocardiogram and apex cardiogram before ( $a$ and c, respectively), and after 2 months of beta-blockade ( $b$ and d, respectively). After beta-blockade there was a return to normal of the third and fourth heart sounds and of the diastolic part of the apex cardiogram (as in Cases 1 and 4). 
TABLE 8 Echocardiography of left atrium and left ventricle before and after chronic beta-blockade in congestive cardiomyopathy

\begin{tabular}{|c|c|c|c|c|c|c|c|c|}
\hline \multirow[t]{2}{*}{$\begin{array}{l}\text { Case } \\
\text { No. }\end{array}$} & \multicolumn{2}{|c|}{$\begin{array}{l}\text { Left ventricular } \\
\text { end-diastolic } \\
\text { diameter }(\mathrm{cm})\end{array}$} & \multicolumn{2}{|c|}{$\begin{array}{l}\text { Left atrial } \\
\text { diameter }(\mathrm{cm})\end{array}$} & \multicolumn{2}{|c|}{$\begin{array}{l}\text { Mean } V_{\mathrm{CF}}{ }^{\star} \\
\text { (circumference/s) }\end{array}$} & \multicolumn{2}{|c|}{ Ejection fraction } \\
\hline & Before & After & Before & After & Before & After & Before & After \\
\hline I & $6-7$ & 5.2 & 5.0 & 3.0 & - & 0.77 & - & 0.48 \\
\hline 2 & - & 6.8 & - & 5.3 & - & -t & - & 0.35 \\
\hline 3 & 8.4 & 8.5 & 3.9 & 4.2 & 0.52 & 0.47 & -‡ & $-\ddagger$ \\
\hline 4 & 6.2 & 6.0 & 4.5 & 3.9 & 0.51 & 0.66 & 0.21 & 0.58 \\
\hline 5 & 6.9 & 7.1 & 4.8 & 4.8 & 0.60 & 0.72 & $-\ddagger$ & $-\ddagger$ \\
\hline 6 & 5.2 & 4.8 & 3.9 & 3.9 & 0.59 & 0.69 & $(0.31) \ddagger$ & $(0.47) \ddagger$ \\
\hline 7 & 5.3 & 4.9 & 2.9 & 2.9 & 0.94 & 1.33 & 0.54 & 0.72 \\
\hline
\end{tabular}

* Mean velocity of circumferential fibre shortening.

† Difficult to calculate mean $V_{c \text { r }}$ because of atrial fibrillation.

$\mp$ Difficult to calculate ejection fraction because of pathological movement of interventricular septum.

patients in sinus rhythm, 4 had strong or very strong fourth heart sounds. These sounds decreased to normal amplitudes after beta-blockade. A similar return to normal of the pulmonary component was seen in all cases except Case 3. Three patients (Cases 3, 4, and 5) had a typical murmur of mitral regurgitation. Since the echocardiograms gave no suspicion of rheumatic changes of the mitral valve, this regurgitation was considered secondary to a dilatation of the left ventricle (see Table 8). The murmur disappeared in Case 4 (Fig. 3), diminished in Case 5, but was unchanged in Case 3.

\section{Left ventricular ejection time}

When expressing left ventricular ejection time as a percentage of the normal (relative left ventricular ejection time) according to Meiners (1958), values below 90 per cent are abnormal. Of the 6 patients, 5 had a relative ejection time below 90 per cent (Table 6), and in 2 of these it was extremely low (Cases 4 and 6). After chronic beta-blockade the left ventricular ejection time was considerably longer in Cases 4 and 6, with lesser increases in the others; no patient showed shortening of the ejection time.

TABLE 9 Daily dosage of digitalis and diuretics just before start of beta-blocker therapy and after 2 to 12 months of treatment

\begin{tabular}{|c|c|c|c|c|c|c|}
\hline $\begin{array}{l}\text { Case } \\
\text { No. }\end{array}$ & $\begin{array}{l}\beta \text {-blockade } \\
\text { (orally) }\end{array}$ & $\begin{array}{l}\text { Digoxin } \\
\text { (orally) } \\
(m g)\end{array}$ & $\begin{array}{l}\text { Frusemide } \\
\text { (orally) } \\
\text { (mg) }\end{array}$ & $\begin{array}{l}\text { Ethacrynic acid } \\
\text { (orally) } \\
(m g)\end{array}$ & $\begin{array}{l}\text { Spironolactone } \\
\text { (orally) } \\
\text { (mg) }\end{array}$ & $\begin{array}{l}\text { Frusemide or } \\
\text { ethacrynic acid } \\
\text { (intravenously) }\end{array}$ \\
\hline \multirow[t]{2}{*}{$\mathbf{r}$} & - & 0.25 & 80 & - & - & - \\
\hline & + & 0.25 & 80 & - & - & - \\
\hline \multirow[t]{2}{*}{2} & - & 0.5 & 160 & - & 200 & $\begin{array}{l}\text { Ethacrynic } \\
\text { acid } 50 \mathrm{mg} \star\end{array}$ \\
\hline & + & 0.5 & 80 & - & - & - \\
\hline \multirow[t]{2}{*}{3} & - & 0.25 & 40 & - & - & - \\
\hline & + & 0.25 & 40 & - & - & - \\
\hline \multirow[t]{2}{*}{4} & - & 0.25 & 80 & - & 二 & - \\
\hline & + & 0.25 & 40 & - & - & - \\
\hline \multirow[t]{2}{*}{5} & - & 0.25 & 40 & - & - & - \\
\hline & + & 0.25 & 40 & - & - & - \\
\hline \multirow[t]{2}{*}{6} & - & 0.25 & 500 & 80 & 200 & Frusemide $80 \mathrm{mg}$ \\
\hline & + & 0.125 & 200 & - & 200 & \\
\hline \multirow[t]{2}{*}{7} & - & 0.25 & - & - & - & - \\
\hline & + & 0.25 & - & - & - & $=$ \\
\hline
\end{tabular}

^ Occasionally during this period. 

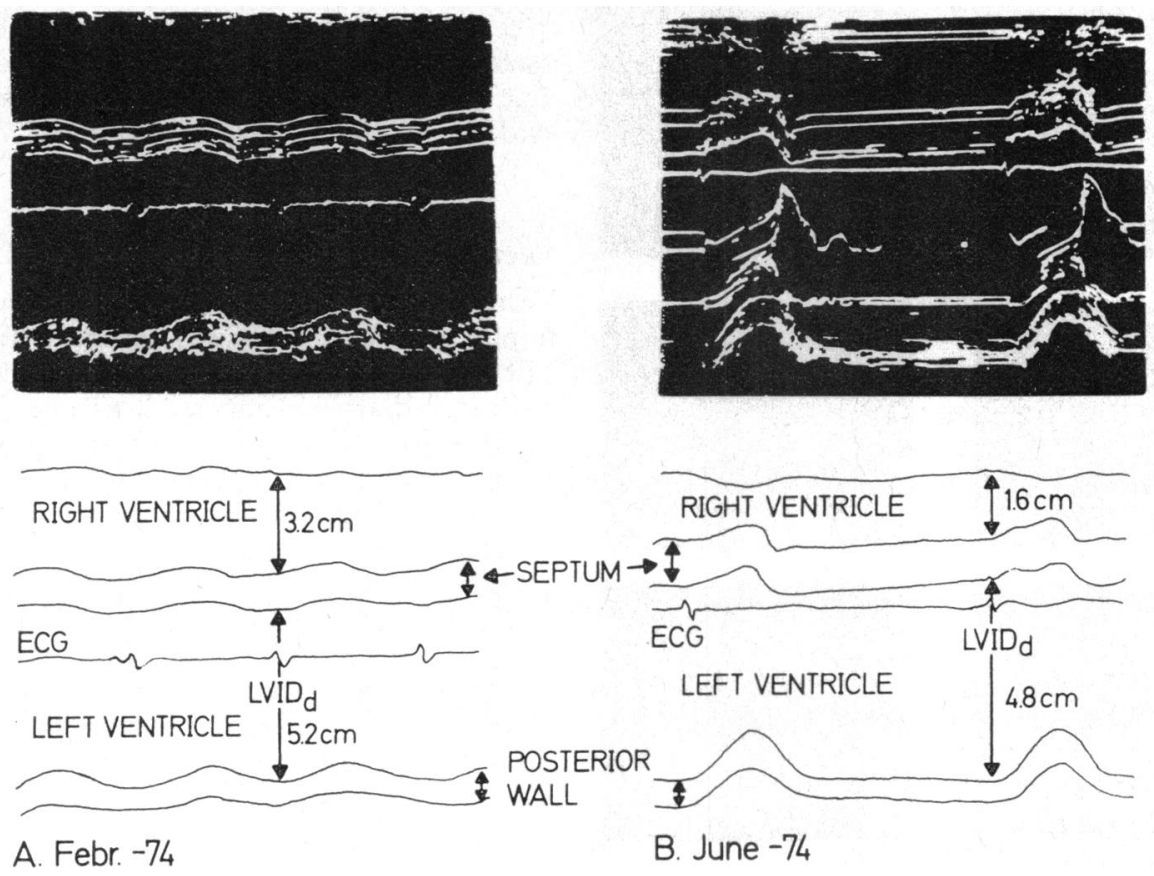

FIG. 5 Case 6. A) February 1974: the right ventricle is dilated and the septum moves towards the anterior wall in systole because of volume load secondary to tricuspid regurgitation. $B$ ) Fune 1974: after 4 months of beta-blockade the anteroposterior dimension of the right ventricle has decreased from 3.2 to $1.6 \mathrm{~cm}$, but the septum still moves anteriorly during systole. A slight decrease of the left ventricular internal diastolic diameter (LVIDd) is also seen.

\section{Apex cardiogram}

All patients in whom measurement could be made had extremely abnormal apex cardiograms, with high rapid filling waves and/or high a waves (Table 7, Fig. 2-4). Both rapid filling waves and the a waves were expressed as a percentage of the total amplitude of the curve $(\mathrm{H})$. After treatment there was a decrease in the rapid filling wave $/ \mathrm{H}$ ratio in all patients except Case 3 and a decrease of the a waves in 2 of them. Fig. 2-4 show the apex cardiograms of Cases $I, 4$, and 7 with complete return to normal after beta-blockade. No changes were seen in Case 3.

\section{Echocardiography}

The left ventricular end-diastolic diameter was very large $(6.2$ to $8.4 \mathrm{~cm})$ in 4 cases and slightly enlarged in Cases 6 and 7 (Table 8 and Fig. 5). It was not measured initially in Case 2. Only a range could be given in Case I before beta-blockade because of poor definition of the endocardium. After beta-blocker treatment this dimension decreased in Cases 1,6 , and 7. There was no change in the other 3 cases. The anteroposterior dimension of the left atrium was enlarged in 3 cases, close to the upper normal limit in 2 cases, and normal in Case 7. After betablockade the left atrium decreased in Cases $I$ and 4 (cf. the changes of the apex cardiogram of these cases, Fig. 2 and 3), probably increased slightly in Case 3, and was unchanged in the others. Since there were abnormal septal movements and therefore asymmetrical contractions of the left ventricle caused by conduction disturbances (Table I) or gross tricuspid regurgitation (Case 6), the ejection fraction could only be calculated in 2 cases before treatment, and it increased after beta-blockade in both of them.

The mean rate of circumferential shortening (mean $\mathrm{V}_{\mathrm{CF}}$ ) was calculated in 5 cases before treatment. This rate increased in all except Case 3. Note that all cases, except Case 7, even after betablockade, had depressed left ventricular function as judged from the mean $V_{C F}$ and the ejection fraction. Case 2, who was only investigated after betablockade, had highly abnormal dimensions and a very low ejection fraction. The dominant clinical disturbance in Case 6 was tricuspid regurgitation, which decreased clinically after beta-blockade The dimension of the right ventricle decreased 



A. Oct. -72

B. Jan. -74

FIG. 6 Case I. Frank leads. Note the decrease of the $Q R S$ loops in all projections after 12 months of beta-blockade. The horizontal maximum before is in October $19722.0 \mathrm{mV}(A)$, in fanuary 1974 I.3 $\mathrm{mV}(B)$. The calibration signal in $H$ is $I \mathrm{mV}$.

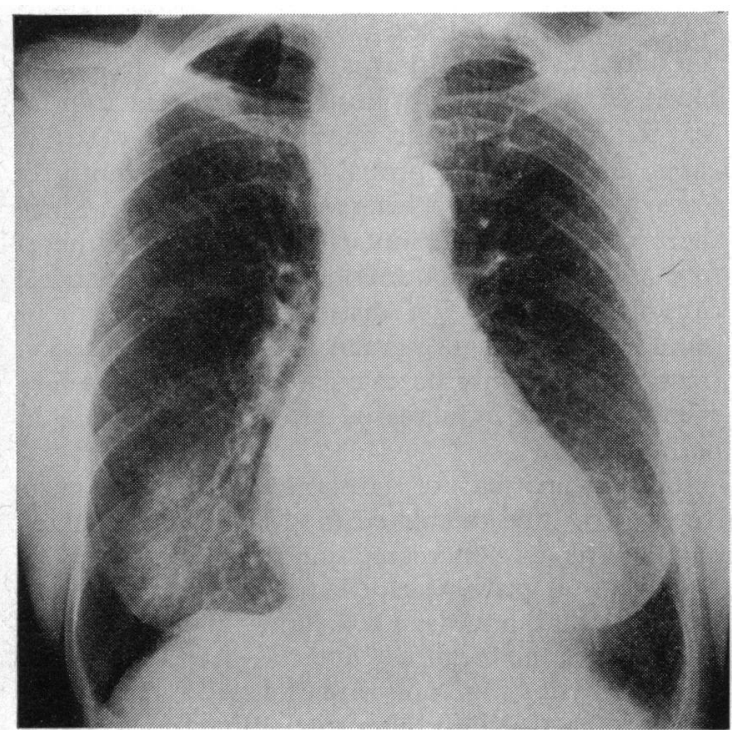

a from 3.2 to $1.6 \mathrm{~cm}$. Probably the left ventricle decreased somewhat and contracted better (Fig. 5). The jugular and hepatic pulse tracings showed less evidence of tricuspid regurgitation.

\section{Vectorcardiogram}

Vectorcardiographic signs of left ventricular hypertrophy were seen in Cases I, 4, and 7. In the other 4 patients there were conduction disturbances which made this diagnosis impossible (Table I). In Cases 4 and 7 new vectorcardiograms were recorded after about 3 months on beta-blockade and showed no significant changes in Case 7 and a small but significant decrease in horizontal maximum vector from $2.8 \mathrm{mV}$ to $2.3 \mathrm{mV}$ in Case 4. In Case I, however, there was a much longer observation period, with 12 months on beta-blockade. This patient showed a remarkable change of the vector loops, with a decrease of the horizontal maximum vector from 2.0 to $1.3 \mathrm{mV}$ (Fig. 6).

\section{Discussion}

Chronic treatment with beta-adrenergic receptor blocking agents in 7 patients with congestive cardiomyopathy over periods ranging from 2 to 12 months

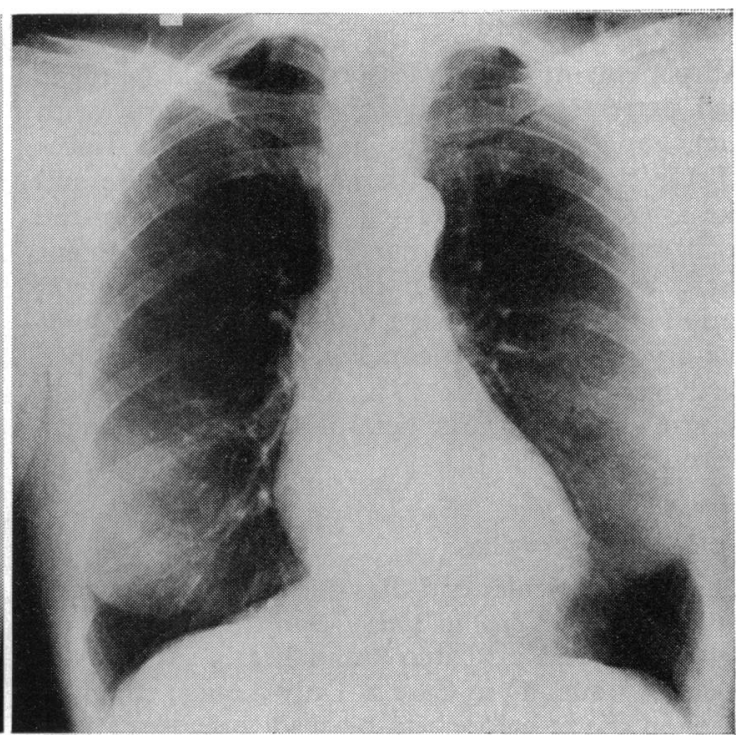

$b$

FIG. 7 Case I. Frontal chest X-ray before (a) and after (b) 12 months of treatment with betablockers showing obvious decrease in heart size. 
resulted in an improved clinical condition with less exertional dyspnoea and retrosternal oppression, allowing the patients increased physical activity. This was reflected in higher physical working capacities at the exercise test. The findings from the noninvasive investigations indicate that heart function was improved during chronic betablockade. In some patients a pronounced reduction in heart size was found during this treatment. In all 7 cases in this study, the relative left ventricular ejection time increased, indicating an increased stroke volume. The $\mathrm{AV}_{\mathrm{O}_{2}}$-difference was studied during exercise in 2 cases and no change was seen in one patient and a reduction from a very high value was seen in the other patient. The improved working capacity in these patients therefore could not have resulted from an increased $\mathrm{AV}_{\mathrm{O} 2}$-difference; it was reached with a lower maximum heart rate and is likely, therefore, to have been attained by higher stroke volumes. This was confirmed in one patient (Case 4) in whom the stroke volume was investigated during maximal exercise using an invasive technique (to be published).

The diagnosis of congestive cardiomyopathy was made according to the criteria of Goodwin and Oakley (1972) who defined the disease as a diffuse primary myocardial disease of unknown origin with a depressed systolic function of the ventricles. Hypertrophic cardiomyopathy has been excluded, as echocardiograms and phonocardiograms showed no signs of outflow tract obstruction or of interventricular septal hypertrophy (Feigenbaum, 1972; Abbasi et al., 1972). Suspected metabolic disorders were excluded by normal levels of urine catecholamines and normal thyroid function tests. A collagen disease was not likely in these patients since the erythrocyte sedimentation rate and the titre of the antinuclear factor were within normal limits. Biopsies from buccal or rectal mucosa showed normal histology. Coronary heart disease was completely excluded only in two patients (Cases I and 6), two woman with no history of chest pain and with normal coronary angiograms. Coronary arterial disease cannot be absolutely excluded in the other cases, but all presented the clinical and haemodynamic features of left ventricular failure as in congestive cardiomyopathy. In 2 (Cases 3 and 5) retrosternal oppression on exercise was present, which disappeared after beta-blockade; angina-like chest pain has been reported in Io per cent of cases with congestive cardiomyopathy despite normal coronary angiograms (Gau et al., 1970). These authors noticed that a $Q S$ pattern could also be seen in patients with congestive cardiomyopathy and normal coronary angiograms. In one patient (Case 6) pressure tracings from both ventricles (to be published) and the form of the apex cardiogram suggested constriction. This was thought to be of myocardial origin. The heart was greatly dilated and additional pericardial constriction was excluded by angiocardiography.

The genesis of congestive cardiomyopathy is generally accepted to be of multifactorial origin but the causes operative in individual cases are rarely identifiable. In 6 of our cases the onset of symptoms occurred shortly after what might have been a virus infection. It is important to stress that none had any signs of infection during the last 3 months before the start of treatment with beta-blockade. Furthermore, the onset of symptoms occurred 6 months to 6 years (average 2.6 years) before the start of beta-blockade. One patient (Case 6), who already had some clinical findings indicating heart disease (enlargement of the heart but no subjective signs), suffered serious progression of her heart disease during the third trimester of pregnancy, shortly after a severe common cold. Intermittent infection may unmask a latent disease or aggravate a pre-existing one.

The management of congestive cardiomyopathy has not changed much during the past decade except for the use of pacemakers in bradyarrhythmias, lignocaine and DC shock in ventricular tachyarrhythmias, and frusemide and spironolactone in the treatment of oedema. The progression of the disease has, however, never been reported to be changed by this therapy, and death often results from a final ventricular arrhythmia. The regimen of prolonged bed rest advocated by McDonald and co-workers (1972) is difficult to administer when permanent improvement cannot be guaranteed. However, a reduction of sympathetic activity during prolonged bed rest comparable to the beta-blockade in this study could possibly explain a reduction in heart size seen in the study of McDonald and co-workers (1972). To use beta-receptor blocking agents in congestive cardiomyopathy seems paradoxical since the heart might be dependent upon raised sympathetic activity. However, reduction of a high heart rate might reduce the energy demand of the myocardium (Braunwald, 1971) and allow better diastolic filling and thus increase the stroke volume, thereby improving the efficiency of the heart and possibly allowing more energy to be used for the contractile work.

In the present study only patients with a steady progression of the disease have been included. The patients had been given conventional treatment with digitalis and diuretics for several weeks in hospital without significant benefit before the start of treatment with beta-blockers. The digitalis and diuretics 
were somewhat reduced after a time on beta-blockers and in some cases even stopped (Table 9). Interruption of beta-blockade in the early stages of treatment was followed by prompt return of symptoms. It, therefore, seems unlikely that the improvement in cardiac function and relief of symptoms observed in this study could have occurred by chance or been a part of the natural history of the disease.

The clinical impression of improvement in the present cases was confirmed by changes in both invasive and noninvasive parameters of left ventricular function. An early effect of depressed left ventricular function is hypertrophy of the left atrium, associated with the increase in end-diastolic pressure and the volume of the ventricle (Romhilt and Scott, 1972; Hammermeister and Warbasse, 1974). The corresponding noninvasive findings are loud fourth heart sounds and high a waves in the apex cardiograms, and it seems well accepted that an a/H ratio more than 15 per cent indicates a pathological end-diastolic pressure (Rios and Massumi, 1965; Epstein et al., 1968; Voigt and Friesinger, 1970; Gibson et al., 1974). When this atrial compensation becomes inadequate the filling pressure has to increase earlier in diastole leading to a rise of the pressure in the pulmonary circulation; this results in pathological third heart sounds, pronounced rapid filling waves in the apex curves, loud pulmonary components of the second heart sound, and sometimes mitral regurgitation if there is dilatation of the left ventricle. In these cases high end-diastolic pressures can be seen with $\mathrm{a} / \mathrm{H}$ ratios below I5 per cent, probably because of insufficient atrial contraction to give enough additional pressure rise. Left ventricular ejection time decreases, mostly because stroke volume is a major factor determining this period (Braunwald, Sarnoff, and Stainsby, 1958; Weissler, Peeler, and Roehll, 1961; Fabian et al., 1972). All patients in this study had several noninvasive findings typical of the last group. If the pump function of the left ventricle improves, these changes can be expected to be reversed. This was seen after beta-blockade, the most pronounced changes being a normalization of the pulmonary components and of the rapid filling waves, and disappearance of the pathological third heart sounds. The changes of the apex curves and diastolic extra sounds shown in Fig. 2 to 4 are remarkable. Such a dramatic return to normal tracings has not been seen in non-surgical cases in spite of experience of more than 5000 non-invasive investigations in our laboratory (Wallentin, unpublished observations).

Echocardiography has been shown to give much better estimation of the left atrial size compared to chest $x$-ray when angiography was used as a stan- dard (Hirata et al., I969). In a study at this hospital it has been found that the echocardiographic anteroposterior dimension of the left atrium is larger in many cases of myocardial infarction and hypertension than in normal individuals of the same age (Wikstrand and Wallentin, to be published). It is also our experience that echocardiography demonstrates that the left atrium is enlarged in cases of severe aortic valvular disease, especially in relation to left ventricular failure, and in many of these cases this dimension decreases again after surgery. Two of our cases with very obvious clinical improvement (Cases I and 4, Fig. 2 and 3) also showed a clear decrease of left atrial size echocardiographically.

Since the lower limit of mean $\mathrm{V}_{\mathrm{CF}}$ is about I circf/s (Paraskos et al., 197I; Cooper et al., 1972) 4 out of 5 cases had unusually low values, depressed to 50 to 60 per cent of this lower limit. In spite of an increase in left ventricular ejection time after beta-blockade, which per se decreases mean $\mathrm{V}_{\mathrm{CF}}$, an increase in mean $\mathrm{V}_{\mathrm{CF}}$ was seen in all patients except one (Case 3) who was unchanged in all noninvasive parameters except the left ventricular ejection time.

Reduction of vectorcardiographic signs of left ventricular hypertrophy in Cases I and 4 suggest reversal of the process of hypertrophy during treatment with beta-blocking agents. At least in Case 4, with unchanged left ventricular end-diastolic diameter, the vectorcardiographic findings could not be influenced by reduction of the heart volume.

It is suggested that the hypertrophy in congestive cardiomyopathy is not just a secondary compensatory change in a failing heart. Animal experiments have shown that administration of catecholamines will increase the rate of heart protein synthesis and thus induce hypertrophy without preceding decompensation (Källfelt, Hjalmarson and Isaksson, to be published). Great efforts have been made in an attempt to develop experimental models of cardiomyopathy. Bajusz and co-workers (1969) have shown that the natural course of the disease in Syrian hamsters with hereditary cardiomyopathy could be accelerated by digitalis and catecholamines when given early in life in a vulnerable phase, and that treatment with beta-blocking agents could inhibit the effect of catecholamines. Jasmin and Bajusz (1973) have shown that verapamil, which has calcium antagonistic properties in the heart cell, could prevent the development of pathological changes in the myocardium of these Syrian hamsters. It might, therefore, be questioned whether high sympathetic tone in humans with cardiomyopathy also will induce an increased rate of protein synthesis, hypertrophy, necrosis, and deterioration of heart function, as found in the animal experiments. 
In the present study one patient with severe congestive heart failure (Case I) was treated with the beta-I- and beta-2-receptor blocking agent alprenolol for 12 months, with very good results. The other 6 patients were given the cardioselective beta-Ireceptor blocking agent practolol for 2 to 12 months, with the same beneficial effect. Both these betablockers have intrinsic sympathetic stimulating activity. Cardioselectivity does not seem to be a prerequisite for the favourable effects of beta-blockade in congestive cardiomyopathy. The intrinsic stimulatory activity of the beta-blockers might be of importance but this does not seem likely in view of clinical and experimental data indicating that chronic high levels of catecholamines could induce cardiomyopathy. This study suggests that the blockade of the adrenergic beta-I-receptors of the myocardium is essential for favourable treatment in congestive cardiomyopathy.

A common feature of all the patients in this study with congestive cardiomyopathy was a high resting heart rate. This is the result of case selection, since the primary idea was to study the effect of betablockade in such patients with tachycardia. It has been suggested that a high heart rate in advanced congestive cardiomyopathy is a compensatory mechanism for depressed systolic function with low stroke volumes. However, in two patients (Cases 4 and 7) a high resting heart rate was seen before any cardiac enlargement had developed.

It is possible that patients with cardiomyopathy of various types might be more susceptible to sympathetic stimulation, which might then have unfavourable effects on the myocardium, as has been seen in animal models. All patients with cardiomyopathy do not show tachycardia, which does not favour the suggestion that a high heart rate per se would induce the pathological changes in the myocardium in these patients. However, a normal or low heart rate does not exclude a high degree of sympathetic influence on the heart cells. It is not known whether chronic beta-blockade is also of value in patients with congestive cardiomyopathy without tachycardia. From this study it is not known whether different types of congestive cardiomyopathy will respond similarly to chronic adrenergic beta-receptor blockade. It is obvious from this study that at least some patients with congestive cardiomyopathy will react very favourably to such treatment. Studies are in progress to evaluate the effect of chronic beta-blockade in various types of congestive cardiomyopathy. It is hoped that this will increase our understanding of the pathophysiology of this disease and strengthen the thesis that treatment with adrenergic beta-receptor blocking agents can influence the progression of congestive cardiomyopathy and prolong life in these patients.

The present study was supported by grants from the Swedish National Association against Heart and Chest Diseases, the Swedish Medical Research Council (B73-03X-2529-04), ICI-Pharma and Hässle AB.

\section{References}

Abbasi, A. S., MacAlpin, R. N., Eber, L. M., and Pearce, M. L. (1972). Echocardiographic diagnosis of idiopathic hypertrophic cardiomyopathy without outflow obstruction. Circulation, 46, 897 .

Bajusz, E., Baker, J. R., Nixon, C. W., and Homburger, F. (I969). Spontaneous, hereditary myocardial degeneration and congestive heart failure in a strain of Syrian hamsters. Annals of the New York Academy of Sciences, 156, ro5.

Braunwald, E. (197I). Control of myocardial oxygen consumption. Physiologic and clinical considerations. American fournal of Cardiology, 27, 416.

Braunwald, E., Sarnoff, S. J., and Stainsby, W. N. (1958). Determinants of duration and mean rate of ventricular ejection. Circulation Research, 6, 319.

Cooper, R. H., O'Rourke, R. A., Karliner, J. S., Peterson, K. L., and Leopold, G. R. (1972). Comparison of ultrasound and cineangiographic measurements of the mean rate of circumferential fiber shortening in man. Circulation, 46, 914 .

Deitrick, J. E., Whedon, G. D., and Shorr, E. (1948). Effects of immobilization upon various metabolic and physiologic functions of normal men. American fournal of Medicine, 4 , 3.

Epstein, E. J., Coulshed, N., Brown, A. K., and Doukas, N. G. (1968). The ' $A$ ' wave of the apex cardiogram in aortic valve disease and cardiomyopathy. British Heart fournal, 30, 591.

Fabian, J., Epstein, E. J., Coulshed, N., and McKendrick, C. S. (1972). Duration of phases of left ventricular systole using indirect methods. II: Acute myocardial infarction. British Heart fournal, 34, 882.

Feigenbaum, H. (1972). Echocardiography. Lea and Febiger, Philadelphia.

Gau, G., Goodwin, J. F., Oakley, C. M., Raphael, M. J., and Steiner, R. E. (1970). Q waves and coronary angiography in cardiomyopathy (abstract). British Heart fournal, 32, 554.

Gibson, T. C., Madry, R., Grossman, W., McLqurin, L. P., and Craige, E. (1974). The A wave of the apexcardiogram and left ventricular diastolic stiffness. Circulation, 49, 44I.

Goodwin, J. F. (1974). Prospects and predictions for the cardiomyopathies. Circulation, 50, 210.

Goodwin, J. F., and Oakley, C. M. (1972). The cardiomyopathies. British Heart fournal, 34, 545.

Hammermeister, K. E., and Warbasse, J. R. (1974). The rate of change of left ventricular volume in man. II. Diastolic events in health and disease. Circulation, 49, 739.

Hartman, H. (1964). Fonocardiografie en pulscurven in het bijzonder bij aortastenose. Thesis, Leiden.

Hirata, T., Wolffe, S. B., Popp, R. L., Helmen, C. H., and Feigenbaum, H. (1969). Estimation of left atrial size using ultrasound. American Heart fournal, 78, 43.

Jasmin, G., and Bajusz, E. (1973). Polymyopathie et cardiomyopathie héréditaire chez le hamster de Syrie. Inhibition sélective des lésions du myocarde. Annales d'Anatomie Pathologique, 18, 49. 
Jonsell, S. (1939). A method for the determination of the heart size by teleroentgenography (a heart-volume index). Acta Radiologica, 20, 325.

Källfelt, B., Hjalmarson, $\AA$., and Isaksson, O. In vitro effect of catecholamines on protein synthesis in perfused rat heart. Fournal of Molecular and Cellular Cardiology. In the press.

McDonald, C. D., Burch, G. E., and Walsh, J. J. (1972). Prolonged bed rest in the treatment of idiopathic cardiomyopathy. American fournal of Medicine, 52, 4I.

Meiners, S. (1958). Messmetoden zur Analyse der Herz- und Kreislaufdynamik. Freiburger Colloquium, 4, 84.

Paraskos, J. A., Grossman, W., Saltz, S., Dalen, J. E., and Dexter, L. (197I). A noninvasive technique for the determination of velocity of circumferential fiber shortening in man. Circulation Research, 29, 6 ro.

Pombo, J. F., Troy, B. L., and Russell, R. O. (1971). Left ventricular volumes and ejection fraction by echocardiography. Circulation, 43, 480 .

Rios, J. C., and Massumi, R. A. (1965). Correlation between the apex cardiogram and left ventricular pressure. American fournal of Cardiology, 15, 647.

Romhilt, D. W., and Scott, R. C. (1972). Left atrial involvement in acute pulmonary edema. American Heart fournal, 83, 328.

Saltin, B., Blomqvist, G., Mitchell, J. H., Jr., Johnson, R. L., Wildenthal, K., and Chapman, C. B. (1968). Response to exercise after bed rest and after training. Circulation, 38, Suppl. VII, $\mathrm{x}$.
Voigt, G. C., and Friesinger, G. C. (1970). The use of apexcardiography in the assessment of left ventricular diastolic pressure. Circulation, 41, I0I5.

Waagstein, F., Hjalmarson, A. C., and Wasir, H. S. (1974). Apex cardiogram and systolic time intervals in acute myocardial infarction and effects of practolol. British Heart fournal, 36, 1 rog.

Weissler, A. M., Peeler, R. G., and Roehll, W. H. (196r). Relationships between left ventricular ejection time, stroke volume, and heart rate in normal individuals and patients with cardiovascular disease. American Heart fournal, 62, 367.

Wikstrand, J., and Wallentin, I. Echocardiographic estimation of left atrial size after myocardial infarction. To be published.

Wikstrand, J., Wallentin, I., and Nilsson, K. The effect of a capillary on the frequency response in an air-filled system for recording of apex cardiogram and carotid pulse tracing. To be published.

Willems, J., and Kesteloot, H. (1967). The left ventricular ejection time. Its relation to heart rate, mechanical systole and some anthropometric data. Acta Cardiologica, 22, 401.

Requests for reprints to Dr. Finn Waagstein, Department of Medicine I, Sahlgrenska Sjukhuset, 4I3 45 Göteborg, Sweden. 